\title{
Procurement at Local Government Level - Issues and Controversies ${ }^{1}$
}

\author{
Marija Kaštelan Mrak \\ University of Rijeka, Faculty of Economics; Rijeka, Croatia \\ kastelan@efri.hr \\ Nenad Vretenar \\ University of Rijeka, Faculty of Economics; Rijeka, Croatia \\ vretenar@efri.hr \\ Jelena Jardas Antonić \\ University of Rijeka, Faculty of Economics; Rijeka, Croatia \\ jjardas@gmail.com
}

\section{ABSTRACT}

Local government, as administrative units, performs a broad range of services that require to establish relations with outside partners, including those belonging to the private sector. Public procurement, due to the size of the involved financial flows, is government activity especially exposed to inefficiencies, corruption and dishonesty. There is an everlasting discussion on the ideal size and the range of services to be kept 'in-house' of local government units (LGUs).Transaction Costs Economics (TCE) represents a theoretical paradigm specially designed to interpret the issue of efficiency in inter-institutional relations. However, even though TCE might be envisaged as a tool for building better systems and institutions, practical experience suggests that efficient organization of complex multi-institutional systems is still a goal to be met. Therefore, public procurement procedures at LGU level are suitable to analyze the transaction costs. In an attempt to determine the main organizational features of the existing scope of institutions/entities involved in delivering services to citizens, we provided an overview of the complexity of inter-organizational relations at LGU level.

In this paper, we present results of an empirical research of public procurement procedures from the perspective of LGUs in Croatia. Picking up on questionnaire responses from 200 LGUs that reported having held over 350 cases of providing services through contract agreements with 'independent' service providers, we formed an opinion of what could be the consequences of developing more structured public procurement procedures.

Keywords: economic efficiency, local government units, public procurement, public administration, transaction costs

JEL: H57, H83, L 14

1 This work has been fully supported/supported in part by Croatian Science Foundation under the project Perspectives of maintaining the social state: towards the transformation of social security systems for individuals in personalized medicine no. IP-2013-11-5709. 


\section{Introduction}

Economic theory explains organizational arrangements as the results of efficient choices. Our motive in this paper was to test this hypothesis on a real life sample.

For at least a decade reforming (reorganizing) the public administration of Croatia has been one of the most often mentioned phrases appearing in national government election campaigns in Croatia, accompanied by the idea of increasing efficiency/quality outcomes of public services. A third noticeable impulse from the electoral campaign rhetoric was the accented bias towards restructuring the public administration system at regional and local level as opposed to a more integrative top-down approach.

However, in all these discussions, as it often happens in political discourse, little evidence (data) has been laid down for the public to come out with their own conclusions; both in terms of the appropriate scope of restructuring (whether just diminishing number of units or employees, or more relevantly redesigning the scope of activities/jurisdiction of LGU) and in terms of expected outcomes. Rather, the impression was that parties were trying to provide slogans that appear as quick-fix solutions. But, once the box was opened and analytical discussion started, dissonant tones appeared and radical changes no longer seem likely.

This research tried to track down data that would provide some evidence of local government organization/management/performance issues. The idea was that a more precise, process-specific oriented empirical analysis would shed more light into the organizational efficiency of local governments, allowing us to assess the scope of activities, human capacity and thus question the existing size of local government units and distributional arrangements (allocation) of tasks and resources. Searching for a representative object to focus our research interest we chose to look at the process of public procurement at local government level.

Public procurement seemed particularly adequate for introducing issues of capacity, efficiency, service quality (quality of life), functional and dysfunctional behaviour; and particularly, as an appropriate activity to try interpreting existing organizational practices though the lens of TCE. In addition, as we had recently been running a questionnaire on public procurement processes at local government level, we believed our questionnaire results could provide some insight into the capabilities and shortcomings of local governments.

Another rationale for picking up public procurement was that public procurement represents important aspect of public administration functioning. Savings in this area should be treated as a contribution to increasing both economic efficiency and the quality of public services. 
According to OECD, efficiency of procurement can be measured using transaction costs and time required for procurement procedures. Efficiency can also be measured by observing the existence of specific practices, such as the use of e-procurement and of aggregation vehicles like framework agreements and consolidated contracts (OECD, 'Procurement - Key Performance Indicators').

According to European Commission: 'Every year, over 250000 public authorities in the EU spend around 14\% of GDP on the purchase of services, works and supplies. In many sectors such as energy, transport, waste management, social protection and the provision of health or education services, public authorities are the principal buyers. Public procurement refers to the process by which public authorities, such as government departments or local authorities, purchase work, goods or services from companies.' (European Commission, 'Public Procurement')

The European Public Procurement Strategy promotes inquiries into the existing organization of public procurement processes: 'By rethinking the entire approach to purchasing, professionalizing public buyers, cutting red-tape, and capitalizing on the benefits of the digital revolution, public administrations can be made more efficient, more effective, and more citizen and business-friendly. Improved governance, the simplification of procedures and the greater use of electronic tools in public procurement are also important instruments in the fight against fraud and corruption. Finally, as the biggest single spender in the EU, the public sector can use procurement to drive key EU 2020 horizontal policies, such as those aimed at creating a more innovative, green and socially-inclusive economy.' (European Commission, 'Public Procurement Strategy')

\section{Theoretical Concerns}

Our basic assumption is that efficiency, being a theoretical concept, is a concept subject to interpretation. Basically, being efficient means doing the right things in the right way. However, what a particular person or community engages in establishing efficient organizational practices, their concepts of efficiency may vary in conformance with underlying theory. This is especially questionable when it comes to interpretations of real life-organizational arrangements and reform efforts.

In the following lines, we try to put down some lines of thought guiding our perception of the issues present in choosing adequate organization frameworks. Under our first subtitle, we take into consideration simple definitions, expressed by public sources, and look at their implications and the alignment of these statements with public discourse on government reforms in Croatia. Under the second subtitle, we dwell on policy statements issued by European authorities. Here again, we try to point to the directions 
that a simple choice of words will imply for the choice of correct measures to be taken in reforming Croatian public administration.

\subsection{A Note on Economic Efficiency}

Economic efficiency is defined in terms of input-output ratios; a more efficient practice is the one requiring fewer resources for achieving a predefined outcome.

The definition above is mainly a 'technical' definition, suitable for textbooks, but requiring additional ramifications and assumptions in order to fit real-life cases. The organizational implication would suggest that a task should be designed and then allocated to the organization unit/organizational level best capable of acquiring and possessing the most adequate bundle of resources. Considering the set of activities needed in public procurement to be more of less stable, the question of how to allocate tasks in a national system of public procurement to become an issue of capacity (Askim, Christensen, Fimreite, \& Lægreid, 2010), particularly human; implying that LGUs that are smaller in size are incapable of providing minimum capacity levels and should thus be considered inefficient. Accordingly, the present public discussion on the size of the Croatian local government sector, with the suggested take of inefficiency being an issue related to an excessive division and stratification of administrative units, appears to be the correct answer to problem of local government efficiency.

Yet, according to our standing, the concept of efficiency is more complex. It is more than just a question of task description, establishing minimum capacity and allocation choices. Considering the passage bellow, representing the often cited explanation by Nicholas Barr, the perception of efficient practices may be 'contaminated' by actors' involvement (theory will call it strategic behaviour of interested parties). Therefore, we should consider the existence of more than just one aspect of efficiency. The first sentence explains the technical aspect, while the second part of the quote widens the efficiency perspective:

'Economic efficiency is about making the best use of limited resource given people's tastes. It involves the choice of an output bundle $X^{\star}=\left(X_{1}, X_{2}, \ldots, X_{n}\right)$ where $X_{i}$ is the output of the $i$ th good, with the property that any deviations form this quantities will make at least one person worst off. (...) In broader definition of efficiency, three conditions must be hold simultaneously. 1. Productive efficiency means that activity should be organized to obtain the maximum output for given input. This is what engineers think when they speak about efficiency. (...) This is not enough for allocative efficiency which requires two additional conditions to hold. 2. Efficiency of the product mix means the optimum combination of goods should be produced, given existing production technology and consumers taste. (...) 3. Efficiency of consumption means that a person's consumption choices should maximize her or his utility - in formal terms the marginal rate of substitution must be equal for all individuals.' (Barr, 2012, p. 44) 
We can assume that specific manifestations of economic activity, that is, in time and place specific cases of organizational arrangements, attitudes towards efficiency are even less amenable to simple interpretations regarding the reached level of efficiency, let alone estimating the prospective or optimizing level of efficiency.

The problem of simplifying the efficiency dilemma is somehow taken up by TCE. TCE maintains that organization forms, or precisely formal institutional boundaries, matter when it comes to efficiency. Basically, TCE reduces the problem of adequate organizational arrangements to the estimation of information requirements required to efficiently govern a transaction. In fact, TCE rearranges our perception of the efficiency issue by stressing the costs (and risks) of information gathering in markets. Market contexts that have become 'contaminated' by market concentration or external factors, such as government interventions, produce higher transaction costs and therefore require more planning, i.e. higher administrative costs. ${ }^{2}$ In short, every transactional relationships demands planning and monitoring thus causing administrative costs. The difference among specific transactions' governing models lies in the amount and pre-planning (formalization) involved.

Thus, alternative organizational forms can vary from very loose normative arrangements that demand little administrative costs, up to fully institutionalized control mechanisms achieved by establishing ownership rights. The standard phrasing would denote that the arm's length relationship is the organizational arrangement most suitable for competitive market situations. A more demanding, and more elaborate arrangement would comprise formal contracting. Ownership relations, that imply the highest sophistication of planning, would represent the best fit for situations involving long-term partnerships, environmental insecurity, institutional insecurity, etc. Efficiency is achieved when the optimal institutional arrangement is chosen for a specific situation. The efficient organizational arrangement will be defined as the one providing the lowest possible level administration costs that can still adequately control for a specific situation; or in organizational terms, efficiency is achieved when the level of imposed behavioural rules (formal organizational arrangements) is kept at minimum level necessary that prevents uninformed (=misguided) decision making. Therefore, efficient organizational arrangements are the least complex sets of norms that can still maintain an adequate level of control over the resource or transaction at stake.

Likewise, the efficiency of the procurement process can be addressed in terms of transaction costs theory and the duration of procurement procedures.

2 Administrative costs can be understood as a redirection of resources towards main purpose (or operational activities) of an organization. In terms of efficiency, as internal, information processing, activities increase their share in total available resources, a reduced supply of goods and services results as a consequence. 
In conclusion, conformance with transaction costs theory, establishing a system of controls (processes, institutions and standards) over public procurement requires setting up measures and procedures that do cause administrative costs, yet these 'investments' can save on the 'costs of using the market'. Efficiency is achieved by balancing the two cost sides. In addition, there is the presumption that to be efficient, control systems should be based on the specific circumstance under which each institution/relationship operates. Therefore, established measures should be pertinent to the activity being controlled, but also conform to the specific administrative capacity of the government unit applying a specific system of controls.

Another pertinent issue, to be kept in mind while developing our research design/arguments, is the ongoing discussion on the adequate size of local government in Croatia that tends to heat up during pre-election times. In consequence, as the public becomes more sensitized to the issue of shaping local government, new facts and data become publicly available and researchers are more likely to get cooperative respondents.

\subsection{Applying Theory to Understanding Implications of Advice on Public Procurement Improvement}

Under this topic, we depict some lines from the European Public Procurement Strategy (EPPS) that carries influences for organizational structuring. Mainly the EPPS points to the importance of public procurement and advises new procedures (transparent web-based system) will have a beneficial effect on the business sector:

'...public procurement is critical to the European economic recovery. Transparent, fair and competitive public procurement across the Single Market creates business opportunities for European enterprises and contributes to economic growth and job creation...'

On January 5, the European Commission adopted the European Single Procurement Document(ESPD) that will considerably reduce the administrative burden for companies, in particular small and medium-sized enterprises (SMEs), who want to have a fair chance at winning a public contract... Today's simplification of the tender procedure is one of the major elements of public procurement reform which will enter into force on 18 April 2016 ... Under the new system, suppliers must state that they are able, upon request and without delay, to provide the supporting documents necessary to prove compliance, unless they are already accessible via public registers.

As explained by the European Commission's Public Procurement Strategy, a web-based system should be established based on a data model that was developed in cooperation with a wide range of stakeholders active in the field of standardization. Funding from the Connecting Europe Facility (CEF) will be made available to facilitate integration of the ESPD into existing electronic procurement solutions. The ESPD will allow for the reuse of data 
filled in by businesses in previous procurement procedures. It is also the entry point for the digitization of the qualification phase of public procurement (Europena Commission, 2016).

The underlined parts of the sentences above have direct implications on how efficiency will be interpreted in practice. Neutral, well-intended statements point to the fact that a simple/exact factor, such as form of disseminating information or integrated European electronic-procurement solutions, will produce desirable results, from standardized procedures, transparency, reuse of data, up to economic growth and job creation. The recommendations, in fact, fit very well with the theoretical definition of efficiency as a technical term suggesting scale economies, the requirement being that tasks should be designed and then allocated to the best fit organization unit/organizational level. However, by suggesting that efficiency can be measured through the 'aggregation vehicles like framework agreements and consolidated contracts' (OECD, 'Procurement - Key Performance Indicators'), might also lead to pronounced redistribution effects comprising the redistribution of authority/activities among levels of government, redistribution of business opportunities between smaller and larger businesses, as well as spatial redistribution of economic activity; all having a much broader socio-economic impact than achieving scale effects in distinct procurement processes.

On first tentative consideration of additional administrative costs, incurred as preparations for the implementation of the above recommendations, we can perceive several 'new investments', such as:

1. The establishment of national or supranational level body authorized to design procedures, set standards, to provide monitoring and eventually undertake coordination activities (a standing body or a coordination procedure);

2. The analysis of the present system of capacity at LGU level, a redesign of LG staff positions and regulations;

3. A review of exiting regulation of LG authority, responsibilities and special laws and regulations;

4. An analysis of the impact on local suppliers. As can be seen from the Strategy, the aggregation of public purchasing is evident ${ }^{3}$. Upon looking at specific public procurement issues such as thresholds, it becomes apparent that local small businesses are not being considered. Only under the presumption that procurement cases

3 The aggregation of public purchasing has started to take hold across the EU. Demand aggregation refers to contracting authorities or others operating through Central Purchasing Bodies (CPBs) which act as wholesalers or intermediaries. Because aggregators manage increasing shares of public procurement markets, they are becoming indispensable players in promoting public procurement reform. Moreover, given their different mandates at political, policy and market level, CPBs are uniquely positioned to implement strategic or innovative procurements. Their role in the standardization of public procurement processes and market insight also play an important role for the professionalization of public administrations.

The Commission intends to support the dissemination of good practice and promote the use of innovative procurement by CPBs and other forms of aggregation of demand. 
with values bellow thresholds will not be required to follow strictly standardized procedures, there would be some space left to accommodate 'local content';

5. An analysis of redistribution of the cost burden. Namely, even though the European Single Procurement Document (ESPD) states that 'considerable reducing of the administrative burden for companies' is expected, there is a possibility that the effect to be achieved is a redistribution of the tax burden of financing public procedures from larger firms to smaller ones. The general public, including small businesses, will finances public expenses, but the changes will benefit the larger companies that are better equipped for entering the electronic bidding process.

In conclusion, with or without explicit intent, organization arrangements appear to be developing towards administratively more and more complex forms. In this area, our primary concern relates to existing administrative capacity at country level. Another concern addresses the redistribution of shares of economics activity inside national boundaries. Namely, the direction towards authority centralization, rather than decentralization, that seems to prevail, suggests a shift of government jobs from local towards central governments. We are concerned that a shift may be imposed by the redistribution of contracts from smaller towards larger firms, ${ }^{4}$ possibly more important for Croatia, than elsewhere in Europe. Finally, we would be interested in analysing the impact of the whole process for the spatial redistribution of levels of economic activity.

\subsection{A Note on Preventing Corruption}

Corruption is a common concern treated in policy documents requiring standardization and professionalization of public procurement practices.

OECD estimates corruption to take away between 20 and 25 per cent of national procurement budgets worldwide (OECD, 2015). They also advocate e-procurement as a measure to fight corruption and offer Korea as an example of good outcomes from obtained by switching to e-procurement. ${ }^{5}$

No one will argue against process analysis that can bring about transparency and time savings. We are in favour of standard, better-structured procurement processed. However, we would also be in favour of researching the wider context that will allow for a better appraisal of the local community outcomes that might (unintendedly) result from the process of establishing new public

4 By keeping high thresholds and demanding staff, equipment, information requirements, smaller firms will be brought into an even more unfavorable position towards larger enterprises competing for bids.

5 The case refers to South Korea's e-procurement system KONEPS that is reported to have saved the public sector 1.4 billion US\$ in costs and the private sector 6.6 billion US\$ compared to the previous paper-based system. The time it took to process the bids dropped from an average of 30 hours to just 2. 
procurement models; such as the aggregation of procurement. However, according to a recent study (European Parliament, 2016, p. 58), Croatia, with a high relative corruption risk, has relatively low costs of corruption because of its low overall value of contracts.

To our understanding, the aggregation of public purchasing is not a measure to fight corruption per se. Aggregation may lead to projects becoming excessively complex or excessively demanding for smaller scale businesses, thus causing a market displacement effect and reducing competition. Concentration on the supply side of the market is a theoretical precondition for raising prices and possibly collusion. The (theoretical) consequence would be higher pricing, so even though payoffs may become less likely (an assumption that deserves to be questioned), the impact government spending will still be negative. Aggregation is also likely to lead to further centralization of decision-making; and therefore, to concentration of authority. We see no argument why officials and staff at higher government levels (and managing larger expendable funds) should be expected to be less susceptible to corruption than those at lower levels of government. Rather, theory would expect the opposite (Yilmaz, Beris, \& Serrano-Berthet, 2008); those that are not controlled by higher levels of authority, those that have more to win by bending, would be expected to fall more easily into temptation.

\section{Public Procurement at LG Level in Croatia}

Local government units in Croatia are, among other state bodies, obligated to follow procedures of public procurement for procurement that exceeds 200,000 HRK in goods and services, or 500,000 HRK in procurement of works (Law on public procurement, NN 90/2011, Amendments of the Law on public procurement, NN 143/2013).

Table 1. LGU types by population and economic power

\begin{tabular}{|l|r|r|r|r|}
\hline & \multicolumn{1}{|c|}{$\begin{array}{c}\text { Municipa- } \\
\text { lities }\end{array}$} & \multicolumn{1}{c|}{ Cities } & \multicolumn{1}{c|}{ Counties } & \multicolumn{1}{c|}{ Zagreb } \\
\hline Average population & 2,957 & 17,668 & 174,744 & 790,017 \\
\hline $\begin{array}{l}\text { Average LGU Budget (2013) in } \\
\text { 000 HRK }\end{array}$ & 7,662 & 120,620 & 182,237 & $7,106,427$ \\
\hline Average LGU Budget per capita & 2,903 & 5,723 & 1,078 & 8,995 \\
\hline Sum budget (2013) in 000 HRK & $3,287,159$ & $15,198,153$ & $3,644,694$ & $7,106,427$ \\
\hline Sum budget as a \% of GDP (2013) & $1.01 \%$ & $4.65 \%$ & $1.12 \%$ & $2.17 \%$ \\
\hline
\end{tabular}

* Zagreb, as a state capital formally has a status as a city and a county) is because of its size and economic power, and in therefore excluded from LGU averages and shown in a separate column.

Source: Ministry of Finance (budgets); Ministry of Public Administrations (population); Statistical Yearbook (GDP)

On the first level of territorial structuring, Croatia consists of 557 cities and municipalities, which together with 20 counties on second structuring level, make up a total of 577 LGUs. However, as it can be seen in Table 1 a vast number of small units are financially rather small in economic power. 
Consequently, on the national scale, the amount of funds used up by public procurement at local government is small.

\subsection{Research Methodology}

Transaction costs economics (TCE) maintain that organizational arrangements saving on the combination of ex-ante and ex-post transaction costs should be considered economically superior. Ex-ante costs are defined as costs occurring during preparation to contracting or by setting-up a behavioural norms and pattern, that is, ex-ante. Mainly these costs are the costs of gathering and processing information and 'bargaining' until a decision is reached. Ex-post costs are considered to be costs of unintended consequences of wrong decisions, including costs of remediating bad outcomes, such as bearing losses, costs of turning to reverting to less favorable (previously discarded) alternatives, switching partners, renegotiating agreements, engaging in dispute settlements arrangements.

Because ex-ante costs are expected to be happening at the present time and since they have a direct, intuitive, influences on activity levels, ex-ante costs are easier to estimate. Likewise, in our research questionnaire ex-ante costs received a more extensive set of questions inquiring into the time and costs that lead into a partnership agreement. Ex-post cots were accessed mainly by inquiring into the number of complaints following a public-procurement process, solicited legal advice and delays caused by disputes.

Basically, organizational arrangement in TCE represents levels of control that can be achieved in a range of interpersonal/interinstitutional relationships. ${ }^{6}$ More complex contractual arrangements are expected to require higher 'set-up' costs for building up safeguards against future, ex-post disruptions in functioning of a planned activity. In our research, the typical organizational arrangements ('levels of control') were represented by:

- short-term contractual arrangement (corresponding to arm's length relationships)

- long-term contractual arrangement (corresponding to long term contractual relations - partnerships)

- ownership (corresponding to 100\% ownership stake or joint ownership with other LGUs)

All three types of organizational arrangements for service delivery exist at LG level in Croatia. Public tendering is considered for cases of short-term contracts and long-term contracts.

6 In O. Williamson's words (1985): 'Progressively increasing the "duration and complexity" of contracts has thus resulted in the displacement of even neoclassical adjustment processes by adjustment processes of a more thoroughly transaction-specific, ongoing administrative kind.' 
As asset specificity (or partner specificity) according to Williamson (1985, 2002) represents a factor that would suggest the desirable level of control over a transaction, we substituted the degree of asset specificity by a functional identification of the contracting object. Respondents were asked to specify the number of deals by each activity area. The offered activity areas were: insurance, parks and green areas maintenance, road maintenance, building and maintenance of educational and sport facilities, and other communal services.

\subsection{Research Sample and Data Gathering Process}

A questionnaire containing 29 questions (some composite) was run in the December of 2014 and addressed to all 577 LGUs in Croatia (municipalities, cities and counties). LGUs could access the questionnaire anonymously by web application. The questionnaire was accessed by 201 respondents. However, the number of respondents on specific questions varied. Among the 201 respondents, 98 identified themselves as municipalities, 81 as cities, and 7 as counties.

It should be noted that the average number of employees employed by the responding LGUs was 63 (mode 4). Further on, they have an average of 4 organizational subunits (mode 1), and 4 employees, on average were included in public procurement procedures (mode 1).

\subsection{Research Findings}

The number of relationships established with other institutions, whether fully owned by LGUs or as partners engaged in a contract arrangement is presented in Table 2.

Table 2. Number of relationships by type

\begin{tabular}{|l|c|c|c|c|c|c|}
\hline TYPE & \multicolumn{2}{|c|}{ Ownership } & \multicolumn{2}{c|}{$\begin{array}{l}\text { Long-term } \\
\text { partnership }\end{array}$} & \multicolumn{2}{c|}{$\begin{array}{c}\text { Arm's length } \\
\text { relationship }\end{array}$} \\
\hline $\begin{array}{l}\text { Number of reposted } \\
\text { relationships }\end{array}$ & \multicolumn{2}{|c|}{103} & \multicolumn{2}{c|}{78} & \multicolumn{2}{c|}{60} \\
\hline \multirow{2}{*}{ Number of partners } & average & mode & average & mode & average & mode \\
\cline { 2 - 7 } & 3.19 & 1 & 3.96 & 0 & 7.15 & 0 \\
\hline
\end{tabular}

In 241 reported partnerships, fully or partially owned firms appear as the most common organizational arrangement for communal services delivery. However, there were still other 138 cases of contracts which might have been established though public procurement. It is interesting to note that the majority of LGUs did not report to 'outsource' service providing at all (Therefore the mode=0).

More analytically, using a question designed to get insight into the complexity, or homogeneity, of transactional relationships, respondents were asked 
to report on the number of public procurement procedures carried out in the past year. The optional answers provided covered common activity areas, such as:

- maintenance of green areas;

- roads maintenance;

- maintenance of schools and educational facilities;

- maintenance of sports, cultural facilities;

- insurance and;

- other communal services.

The answers obtained are presented in Table 3.

Table 3. Number of public-procurement procedures run in 2013 by area of activity

\begin{tabular}{|l|c|c|c|c|}
\hline Activity area & Number & Mode & $\%$ & Average \\
\hline Green areas & 27 & 0 & 10.96 & 0.30 \\
\hline Roads & 42 & 1 & 17.07 & 1.55 \\
\hline Education facilities & 45 & 1 & 18.29 & 1.07 \\
\hline Culture \& Sports & 48 & 1 & 19.51 & 1.33 \\
\hline Insurance & 31 & 0 & 12.60 & 0.42 \\
\hline Other activities & 54 & 1 & 21.95 & 9.09 \\
\hline Total reported & 246 & \multicolumn{5}{|l}{} \\
\hline
\end{tabular}

We were also interested in the influence of repeated contracting with same partners on transaction costs, as there was a $68 \%$ of positive answer to the question on whether there were savings to be achieved in repeated bargaining. Therefore, we tried to compare long-term and short-term partnerships; yet comparing only total sums, we found no evidence of preferences towards either long- or short-term partnerships. As can be seen in Table 4, the number and structure of long-term and short-term (arm's length) were reported to be at similar level of activities for both types of contract arrangements for management of green areas. Infrastructure maintenance, expectedly, relied more on long-term partnerships, while unnamed (the answer chosen being: other activities) demonstrated a higher proportion of short-term arrangements.

Table 4. Number of long-term and short-term contract relations with partner firms (2013)

\begin{tabular}{|l|c|c|c|c|}
\hline \multirow{2}{*}{ Activity area } & \multicolumn{2}{|c|}{ Long-term } & \multicolumn{2}{c|}{ Short-term } \\
\cline { 2 - 5 } & number & average & number & average \\
\hline Green areas & 33 & 0.36 & 32 & 0.38 \\
\hline Roads & 46 & 1.09 & 42 & 0.79 \\
\hline Water management & 37 & 0.49 & 30 & 0.27 \\
\hline Waste management & 43 & 0.60 & 30 & 0.27 \\
\hline Other & 36 & 2,03 & 37 & 4.70 \\
\hline Total sum & 195 & & 191 & \\
\hline
\end{tabular}


Summing up long-term and short-term contractual agreements, we get a number of 386 partnerships reported with just a little above the number of partnerships existing between LGU and firms held under their ownership (listed in Table 5).

Table 5. Number of relations with partner firms in LG ownership (2013)

\begin{tabular}{|l|c|c|c|c|}
\hline Activity area & Owned & Average & Mode & $\%$ \\
\hline Green areas & 82 & 0.94 & 1 & 23.91 \\
\hline Roads & 51 & 0.82 & 1 & 14.87 \\
\hline Water management & 80 & 1.04 & 1 & 23.32 \\
\hline Waste management & 81 & 1.07 & 1 & 23.62 \\
\hline Other & 49 & 2.61 & 1 & 14.29 \\
\hline Total sum & 343 & \multicolumn{5}{|l}{} \\
\hline
\end{tabular}

This could suggest that in Croatia a large proportion of local services (here estimated only by number, not value) are performed by publicly owned firms. This is consistent with a mode value of 1 suggesting that forms of service providing requiring stability in quantities and service quality (water and waste management) were served by firms held in ownership relations. However, and such is the case of smaller LGUs, it is also quite common to have supplementary works arranged for service provision (maintenance) with independent contractors. It would be interesting to compare the value/ costs ratios of services being performed under different organizational arrangements. However, at this time we did not have the necessary financial data at our disposal. ${ }^{7}$

The problem of transaction costs estimation was addressed by establishing the duration of different stages of procurement process. Our respondents $(n=71)$ on average estimate of the total duration of a public procurement procedure, from opening the bidding process the picking up the contracting party, to be 49.25 days. As a rule, for each tender there were 3 offers, with the average number of tender offers being estimated at 3.46. This suggests that we should consider the number of bidders to be influenced primarily by legal requirements, not so much by some different pricing strategies being exerted by bidders, because of which LGUs will would be interested in carrying out analytical research into price/value ratios of submitted proposals.

Again, the comparison of average duration of procedures by stages, suggests very similar time structures independent of contracting object. Again, we suspect the common reason for these similarities to be the legal requirements. ${ }^{8}$ Ex-ante activities, from starting tender preparations to running tender procedure were estimated to last on average a little bit

7 We would need to map cost/value relations under different organizational arrangements and see whether shifts occur between costs borne by different constituencies, between administration and operation cots and between ex-ante and ex-post costs.

8 On the other hand, there is also the fact that the mode for the number of persons involved in public procurement process at the LGU side to be 1 (average $=4$ ), so that we could also reason that once a person establishes a routine, he will stick to it. Still this is less likely. 
over the duration required by legal requirements. Again, we tried to get data on eventual differences in time structure depending on type of service activity. The figures are demonstrated in Table 6.

Table 6. Duration of public procurement by process stage for different types of services (days)

\begin{tabular}{|c|c|c|c|c|}
\hline \multirow{6}{*}{$\begin{array}{l}\text { Communal services } \\
\text { (excluding water, } \\
\text { sanitation and waste } \\
\text { management) }\end{array}$} & \multicolumn{2}{|c|}{ Preparation of documentation } & \multicolumn{2}{|c|}{$\begin{array}{l}\text { Submission of tender } \\
\text { proposals }\end{array}$} \\
\hline & average & mode & average & mode \\
\hline & 31.34 & 30 & 30.36 & 10 \\
\hline & \multicolumn{2}{|c|}{ Extension of bidding process } & \multicolumn{2}{|c|}{$\begin{array}{c}\text { Processing proposals anc } \\
\text { making choice }\end{array}$} \\
\hline & average & mode & average & mode \\
\hline & 6 & 5 & 23.71 & 20 \\
\hline \multirow{6}{*}{$\begin{array}{l}\text { Maintenance of } \\
\text { educational, cultural } \\
\text { and sport facilities }\end{array}$} & \multicolumn{2}{|c|}{ Preparation of documentation } & \multicolumn{2}{|c|}{$\begin{array}{l}\text { Submission of tender } \\
\text { proposals }\end{array}$} \\
\hline & average & mode & average & mode \\
\hline & 32.04 & 30 & 28.04 & 20 \\
\hline & \multicolumn{2}{|c|}{ Extension of bidding process } & \multicolumn{2}{|c|}{$\begin{array}{l}\text { Processing proposals anc } \\
\text { making choice }\end{array}$} \\
\hline & average & mode & average & mode \\
\hline & 7.28 & 10 & 25.58 & 20 \\
\hline \multirow{6}{*}{$\begin{array}{l}\text { Building and } \\
\text { maintenance } \\
\text { of business } \\
\text { infrastructure }\end{array}$} & \multicolumn{2}{|c|}{ Preparation of documentation } & \multicolumn{2}{|c|}{$\begin{array}{l}\text { Submission of tender } \\
\text { proposals }\end{array}$} \\
\hline & average & mode & average & mode \\
\hline & 33.52 & 30 & 25.94 & 10 \\
\hline & \multicolumn{2}{|c|}{ Extension of bidding process } & \multicolumn{2}{|c|}{$\begin{array}{c}\text { Processing proposals an } \\
\text { making choice }\end{array}$} \\
\hline & average & mode & average & mode \\
\hline & 7.41 & 10 & 25.19 & 20 \\
\hline
\end{tabular}

\subsection{Remaining Issues Related to Research Results}

It was very interesting to read the free written comments of respondents. Respondents, being personally involved in public procurement processes suggested correction could be made in the public-procurement process in terms of duration of certain process-phases, penalizing unreasonable complaints (complaints that one person described as being stated solely in order to boycott the process or competitors). In fact, out of 13 written comments, 6 pointed to the need to further regulate the bidders' complain process.

Four respondent inputs stressed the problem of selecting bidders upon price; what is commonly criticized is the legal definition of 'best offer' as being the lowest cost offer and the consequent 'implied guilt' for acting in favour of specific bidder every time the object of transaction is ex-ante specified in more details. 
The respondents' reasoning is conformant with theory expectations. For instance, according to Raiffa (2007, p. 178), in negotiations with multiple bidders, with competitive sealed bids, the lowest price will be reached when bidders believe that other bidders will offer selling at a lower price. Because of information asymmetry, bidders are, or can be, unaware of the number of other competitors and therefore psychologically persuaded to offer low price even when they are the only interested seller.

Along this same line of reasoning, that ex-ante costs are incurred in order to control ex-post costs, theory would, in fact, suggest that as object or relationship sophistication increases, the more structured should be the bidding process and more elaborate the contract items. When the object of procurement is standardized, public procurement should prove beneficial in reaching the best price, but problems could arise when procuring goods or services with higher level of complexity. For example, complexity can arise in a form of questionable quality of future product or provided service. Even when LGUs devote significant effort into including as many quality and other requirements in their tender documentation, thus generating higher ex-ante costs, some problems can still be overseen and might create future ex-post cost. Therefore, more complex contractual arrangements could be better fitted for private-ordering deals rather than public procurement.

Public procurement can be seen as a way to reach impersonal exchange. In that kind of relations everyone is treated the same whether they are personally known to each other or not (Wallis, 2011). However, although impersonality is, from perspective of institutionalism, important concept in economic development, it is still highly theoretical. To avoid ambiguity economic subjects are aiming to know at least social identity of their counterparts, which, as they believe, should make future disputes less likely and easier to solve. Moreover, Halonen-Akatwijuka and Hart $(2015$, p.4) argue that using continuous contracts instead of arm-length ones might prove beneficial. In their own words, with continuing contracts 'there is no obligation to trade in the second period but if there are gains from trade the parties will bargain using the first period contract as a reference point.' Therefore, by using private ordering, quality concerns and other ambiguities could be avoided or easier to handle. That perhaps comes only at risk of not reaching the best price or opening extra space for corruption activities.

\section{Conclusion}

Local government performs a broad range of services that require LGUs to establish relations with 'outside' partners, including those belonging to the private sector. Therefore, they represent a suitable unit of analysis when treating transaction costs. In a attempt to determine the main organizational features of the existing scope of institutions/entities involved in delivering services citizens, this paper provides an overview of the complexity 
of inter-organizational relations at LGU level. The findings are based on data collected through anonymous questionnaires sent to all Croatian LGUs. Transaction costs were addressed indirectly, mainly by establishing the hardships of establishing and maintaining a transaction relationship.

LGU units accomplish an important share of their activities by engaging in contractual relationship with private sector companies. Since the nature of these relationships may have long terms implications for service quality and costs to be born by society, there are benefits that can be expected from a well-designed system or regulating a common and reiterating activity. However, the dilemma exists concerning the appropriate level of standardization, as well as the attributes of the transaction 'deserving' to be streamlined in order to optimize cost (and process time) during planning activities and during implementation.

Our research demonstrated conformity of procedures and organizational arrangements that surpass the expectations of economic theory reasoning on efficiency. Mainly, the same patterns of contracting existed for smaller and larger financial capacity and any other distinctive feature that might have been expected to imply different distribution of tasks. In fact, even the time frame of individual process stages was very uniform across our whole sample, and vaguely depended on field of activity (which, in theory, would have corresponded to variables of task complexity, duration, market transparency, partner dependency, etc.).

Precisely, transactions have been observed to occur in two separate categories: a) transactions of LGUs with wholly owned communal firms and b) transactions with private entities occurring in regular public procurement bids. Our rationale was that even though the first relationship represents a stable system formally controlled by the LGU, therefore theoretically less exposed to transaction risks/costs, both systems are administered by the same personnel, suggesting that both sorts of transactions are covered by the same (scarce) administrative capacity. 
Marija Kastelan Mrak, PhD is a full professor on several courses in field of organization from pre-graduate to doctoral level and head of postgraduate specialist study program Public Sector Management at Faculty of Economics, University of Rijeka, Croatia. Her scientific interest focuses on economic theories of organization, more recently her interest extends to public administration regulation economics

Nenad Vretenar, PhD is an assistant professor on courses Organization and Economics of Rational Behaviour at Faculty of Economics, University of Rijeka, Croatia. His scientific interest is mainly focused on the fields of organization and management, rational behaviour and decision-making.

Jelena Jardas Antonic, PhD is an assistant professor on courses Mathematics, Mathematical Analysis, and Actuarial Mathematics at Faculty of Economics, University of Rijeka, Croatia. Her scientific interest is mainly focused on the fields of mathematics and economics of security. 


\section{References}

Askim, J., Christensen, T., Fimreite, A. L., \& Lægreid, P. (2010). How to Access Administrative Reform? Investigating the adoption and Preliminary Impacts of the Norwegian Welfare Administration Reform. Public Administration, 88(1), 232-246. doi:10.1111/j.1467-9299.2010.01809.x

Barr, N. (2012). Economics of the Welfare State (5th ed.). Oxford University Press.

Halonen-Akatwijuka, M., \& Hart, O. (2015). Short-term, Long-term, and Continuing Contracts (NBER Working Paper No. 21005, issued in March 2015). National Bureau of Economic Research.

Raiffa, H. (2007). Negotiation Analysis: The Science and Art of Collaborative Decision Making. The Belknap Press of Harvard University Press.

Wallis, J. J. (2011). Institutions, Organizations, Impersonality, and Interests: The Dynamics of Institutions. Journal of Economic Behavior \& Organization, 79(1-2), 48-66. doi:10.1016/j.jebo.2011.02.002

Williamson, O. E. (1985). The Economic Institutions of Capitalism. Yale University, Mac Millan Press.

Williamson, O. E. (2002). The Theory of the Firm as Governance Structure: From Choice to Contract. Journal of Economic Perspectives, 16(3), 171-195. doi:10.1257/089533002760278776

Yilmaz, S., Beris, Y., \& Serrano-Berthet, R. (2008). Local Government Discretion and Accountability: A Diagnostic Framework for Local Governance. Local Government and Accountability Series (Paper No. 113).

Croatian Bureau of Statistics. (2014). Statistical Yearbook of the Republic of Croatia. Retrieved 1. 4. 2016, from http://www.dzs.hr/

European Commission (2015, November). New Directives on public procurement and concession contracts will enter into force on 18 April 2016. Retrieved 1. 4. 2016, from http://ec.europa.eu/growth/tools-databases/newsroom/cf/ itemdetail.cfm?item_id=8562

European Commission (2016, January). Commission further simplifies public procurement across the EU. Retrieved 1. 4. 2016, from http://ec.europa.eu/ growth/tools-databases/newsroom/cf/itemdetail.cfm?item_id=8611

European Commission (n.d.). Efficient public administration. Retrieved 1. 4. 2016, from http://ec.europa.eu/regional_policy/en/policy/themes/ better-public-administration/

European Commission. (n.d.) Horizon 2020: Connecting Europe Facility. Retrieved 23. 3. 2016, from https://ec.europa.eu/digital-single-market/en/ connecting-europe-facility\#Article

European Commission (n.d.). Public procurement. Retrieved 23.3.2016, from http://ec.europa.eu/growth/single-market/public-procurement/index_ en.htm

European Commission (n. d). Public procurement strategy. Retrieved 23. 3. 2016, from http://ec.europa.eu/growth/single-market/publicprocurement/strategy/index_en.htm

European Parliament (2016, March). The Cost of Non-Europe in the area of Organised Crime and Corruption, Anex 2 - Corruption. Retrieved 4. 4. 2016, from http://www.europarl.europa.eu/RegData/etudes/STUD/2016/579319/ EPRS_STU\%282016\%29579319_EN.pdF

OECD. (2007). Integrity in Public Procurement: Good Practice from A to Z. Retrieved 1. 4. 2016, from www.oecd.org/development/effectiveness/38588964.pdf 
OECD (2015, March). Transparency in public procurement - moving away from the abstract. Retrieved 30. 3. 2016, from http://oecdinsights. org/2015/03/27/transparency-in-public-procurement-moving-away-from-theabstract/

OECD. (n.d.). Procurement - Key Performance Indicators. Retrieved 29. 3. 2016, from http://www.oecd.org/corruption/ethics/procurement-key-performanceindicators.htm

Zakon o javnoj nabavi. NN 90/2011. Retrieved 7. 4. 2016, from http://narodnenovine.nn.hr/clanci/sluzbeni/2011_08_90_1919.html

Zakon o izmjenama i dopunama zakona o javnoj nabavi. NN 143/2013. Retrieved 7. 4. 2016, from http://narodne-novine.nn.hr/clanci/ sluzbeni/2013_12_143_3068.html 


\subsection{Izvirni znanstveni članek}

\section{Naročila na ravni lokalne samouprave - težave in polemike}

Javna naročila so pogosto prepoznana kot aktivnost, v katero so vključeni znatni finančni tokovi, velikokrat pa so tudi predmet slabega vodenja, celo goljufij. Zato javna naročila urejajo številni zakoni in standardi.

Po mnenju OECD je učinkovitost naročila mogoče izmeriti z uporabo transakcijskih stroškov in časa, potrebnega za postopke naročanja. Učinkovitost je mogoče izmeriti tudi z opazovanjem obstoja določenih praks, kot sta uporaba e-naročanja in združevanja orodij, kot so okvirni sporazumi in skupinske pogodbe. Ekonomija transakcijskih stroškov (ETS) predstavlja teoretično paradigmo, posebej oblikovano za interpretacijo vprašanja učinkovitosti v medinstitucionalnih odnosih. Čeprav je ETS mogoče videti kot orodje za izgradnjo boljših sistemov in institucij, praktične izkušnje kažejo, da je učinkovita organizacija kompleksnih večinstitucionalnih sistemov še vedno cilj, ki bi ga bilo treba doseči. Takšno stališče je podprto s Tematskim ciljem EU 11, ki poudarja potrebo po ustvarjanju stabilnih, vendar fleksibilnih organizacijskih ureditev, ki zagotavljajo javne storitve kot enega izmed prihodnjih ciljev. V skladu s teorijo transakcijskih stroškov zahteva vzpostavitev sistema nadzora nad procesom javnega naročanja vzpostavitev sistema ukrepov (procese, institucije in standarde, ki delujejo povezano, je mogoče razumeti kot sistem nadzora). Predpostavka učinkovitosti mora temeljiti na določenih okoliščinah, v katerih deluje vsak specifični sistem/institucija/odnos. Zato se mora sistem ukrepov nanašati na nadzorovano dejavnost (specifično funkcijo ali storitev), vendar mora biti tudi skladen s specifično administrativno zmogljivostjo enote, ki izvaja sistem nadzora. Namen tega članka je prispevati k razvoju učinkovitega javnega sistema s proučevanjem konteksta določene situacije na ravni lokalne samouprave na Hrvaškem.

Drugo relevantno vprašanje je sedanja razprava o velikosti lokalne samouprave na Hrvaškem in o njenih pristojnostih. Razprava o idealni velikosti in številu enot lokalne samouprave postane zlasti aktualna v predvolilnem času. Široki razpon storitev administrativnih enot lokalne samouprave, ki zahteva vzpostavljanje odnosov z zunanjimi partnerji, vključno s tistimi, ki pripadajo zasebnemu sektorju, pomeni primerno osnovo za analizo pri obravnavi transakcijskih stroškov. Ta raziskava poskuša določiti glavne organizacijske značilnosti obstoječega nabora institucij/enot, ki so vključene v zagotavljanje storitev za državljane, in tako omogoča pregled kompleksnosti odnosov med organizacijami na ravni lokalne samouprave. 
Ugotovitve raziskave temeljijo na podatkih, zbranih z anonimnimi vprašalniki, ki so bili poslani na naslov vseh hrvaških enot lokalne samouprave. Na podlagi izbora odgovorov 200 respondentov, ki so poročali o 350 primerih zagotavljanja storitev prek pogodb z neodvisnimi ponudniki storitev, se je oblikovalo mnenje o posledicah razvoja bolj strukturiranih postopkov javnih naročil. Transakcijski stroški so bili obravnavani posredno, predvsem z razkritjem težav pri vzpostavljanju in vzdrževanju transakcijskega razmerja. Transakcije so bile opazovane kot dve ločeni kategoriji: a) transakcije z občinskimi podjetji $v$ polni lasti in b) transakcije z zasebnimi enotami, ki se pojavljajo pri rednih ponudbah v javnih naročilih. Čeprav prvi odnos predstavlja stabilen sistem, ki ga formalno nadzoruje enota in je tako teoretično manj izpostavljen transakcijskim tveganjem/stroškom, oba sistema upravlja isto osebje, kar pomeni, da sta obe vrsti transakcij pokriti in omejeni z enako administrativno zmogljivostjo.

Raziskava je poudarila izrazito skladnost postopkov in organizacijskih ureditev s pričakovanji ekonomskih teorij. Enaki vzorci sklepanja pogodb so obstajali za posle manjšega in večjega obsega ter katerekoli druge razločevalne značilnosti, za katere se bi pričakovala drugačna razdelitev nalog. Dejansko je bil v celotnem vzorcu tudi časovni okvir individualnih faz procesa zelo enoten in je bil le malo odvisen od terenske dejavnosti (ki bi v teoriji ustrezala spremenljivkam kompleksnosti naloge, trajanju, tržni transparentnosti, partnerski odvisnosti itd.). 